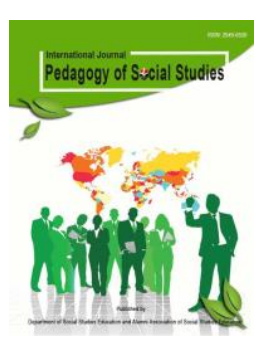

\author{
International Journal Pedagogy of Social Studies
}

\title{
Origin Pattern Care of Orphanage in Developing Children`s Social Skills
}

\author{
Syifa Rohmatin ${ }^{1}$, Siti Nurbayani ${ }^{2}$, Neiny Ratmaningsih ${ }^{3}$ \\ Social Studies Education Study Program, Faculty of Social Sciences Education, \\ Universitas Pendidikan Indonesia, Bandung, Indonesia
}

\begin{abstract}
This research is motivated by phenomena that occur and are faced by children in orphanages, which is related to the problem of transition of residence, different characteristics and backgrounds of children, but requires them to be able to adapt themselves to the orphanage environment. Therefore social skills become a capital that must be possessed by children. The purpose of this study is to describe the parenting practices adopted by the orphanage caretaker in developing children's social skills, know how the implementation of parenting is applied, inhibiting factors, and the efforts made by the orphanage caretaker in developing children's social skills. This study used a qualitative approach with descriptive methods. Data collection techniques are done by observation, deep interview, and documentation. The findings of the research revealed that: (1) The pattern of adoption is democratic parenting which is illustrated through the form of care provided. (2) Implementation of parenting that is applied is through several processes, namely adaptation carried out through an interpersonal approach, Goal attainment is done through the inculcation of social values, Integration is carried out through communication and coordination between parties, and Latency which is carried out through routine evaluation. (3) The inhibiting factors experienced are the limitations of caregivers, different backgrounds and characteristics of children, and environmental factors. (4) Efforts which made are the caretaker and caregivers to establish good coordination and communication, take a personal approach to each child, give advice, reprimand, punishment and motivation, establish coordination with the school, and conduct regular evaluations.
\end{abstract}

Keywords: Parenting, Orphanage Caretaker, Children's Social Skills

Correspondence. syifarohmatin31@gmail.com

Article History. Received January 2020, Received in revised April 2020, Accepted June 2020

C2020. International Journal Pedagogy of Social Studies. Department of Social Studies Education

\section{A. INTRODUCTION}

As a social creature, an individual cannot escape from the existence of his environment. In life, between humans it needs each other. The existence of this mutual relationship that requires each other then makes human life to interact with each other, or better known as social interaction. Therefore, harmony is needed in relationships between individuals so that interactions that occur can meet the livelihood of life. Social skills are the main capital that must be possessed to support this.
Purnamasari (2016, p. 8) suggested that social skills are the ability of children to respond effectively and beneficial for the social environment. This skill is a capital so that children are able to adjust well, and socially acceptable.

This social skills have a huge contribution in achieving one's happiness. Especially for a child, success in establishing interaction with the social environment in particular with peers will greatly influence the process of further development. 
Suhartiwi (2017, p. 50) in his journal stated that "For a child to make friends or get along is part of the socialization process and valuable experience for his future life. In this open world he can feel more meaningful and have a pleasant life. "

Children who have social skills with a good environment usually can overcome various problems in the association. They have no difficulty in developing relationships with new friends, communicate effectively with others, engage in pleasant conversation, and have the ability to end the conversation without disappointing or hurting others.

On the other hand Widyastuti (2011, p. 2) argues that children's social relationships that are not good will make children unable to master emotions, particularly negative emotions such as anger, sadness, frustration, and lack of self-control skills that lead to aggressive behavior, thus making children live unhappy. Many things make it difficult for children to have good interpersonal relationships, one of which is associated with patterns of behavior that are taught at home, this depends on the pattern of child care in the family.

Parenting is the way care is done by parents in the family as the embodiment of their affection to their children. Parenting is also an attitude of the parents in giving discipline, reward, punishment, caregiving, and other responses that affect the formation of the child's personality. (Mahmud et al: 2013, pp. 149-150; Divine: 2013, pp. 135)

From the above opinion it can be concluded that parenting is a pattern or system that is implemented to maintain, maintain, and provide education in general applied by parents. Applying proper parenting is expected to form a child with a good personality,
Independent, disciplined, also has a passionate personality in learning, so that this parenting pattern has factors that will determine children's development later. Otherwise, errors of parenting committed by both parents, one of which can cause various problems faced by children in the development process.

This is in line with Lestiawati (2013) in the results of her research which explains that there is an influence on children's social abilities with the adoption of parenting provided by parents. With the results of testing the research hypothesis which states that there is an influence of children's social abilities with democratic parenting is better than an authoritarian parenting.

This is reinforced by the results of calculations performed in his research. Madjid. et al (2016, p. 2) suggest that parents are the main figure model for children, because parents have ample opportunities to socialize the rules, values, and habits and attitudes to life. But in reality, not all children are fortunate in treading their lives, some children are faced with the choice that the child must separate from his family for some reason.

Like being a child without a mother, a child without a father or even an orphan, do not have relatives who are willing or able to care so that children experience neglect. This results in the psychological needs of children to be less well fulfilled. Fostering of abandoned children is necessary for the formation of personalities intact for the creation of complete quality human resources, so that it can play a role in development. As a concrete form of government effort and concern in overcoming this problem is in the form of the establishment of a social welfare institution for children, orphanages. 
Gospor Nabor (in Bardawi Barzan: 1999, p. 5) explains that "Orphanage is a social service institution established by the government and the community, which aims to help or provide assistance to individuals, community groups in an effort to meet the needs of life ".

It is also related to the social development of children in orphanages. Children in orphanages also need good social skills, as one way to adjust themselves to their social environment. So that when children are equipped with these social skills, children are able to live well in society in the future.

Researchers conducted a study in order to determine how parenting orphanage, with steps to conduct research in the form of observation, interviews, observing and recognize the care patterns of orphanage caretakers in developing children's social skills. The place of research conducted by researchers is the orphanage of Insan Kamil Mandiri. Orphanage of Insan Kamil Mandiri, located at Jalan Cihanjuang Rahayu No. 81 B, Cibabat Village, North Cimahi District, Cimahi City is an institution that serves and is responsible for educating, provide a decent livelihood, and can educate and improve the lives of abandoned children, who do not have parents, and caregivers function as a substitute for the role of parents.

Insan Kamil Mandiri Orphanage is an institution created to prioritize affection and instilling educational and religious activities for children, especially in children who lack attention in continuing formal education. As with one of the missions in this orphanage is to develop patterns of service, assistance, and social protection in order to prevent and overcome children's social problems.

Various backgrounds of children, ages of children, and thedifferent characteristics of children can be found in the Insan Mandiri Kamil Orphanage. As an example of their different places of origin, some came from Medan, Garut, Sukabumi, Tasikmalaya, Bogor, Kebumen, Ciamis and so on, then different family backgrounds from starting children who come from families no mothers, no fathers, orphans, even children who come from their mother's father who has economic limitations, so that the parents are unable to meet the needs of their children's lives so that the child is finally deposited at the Insan Kamil Mandiri Orphanage. Based on the explanation above, Researchers are interested in conducting research under the title "Origin Pattern Care Of Orphanage In Developing Children's Social Skills ".

\section{B. METHODS}

In this study, researchers used a qualitative approach. Sugiyono (2008, p. 15) argues that "qualitative research is a study used to examine natural object conditions. Where researchers are as key instruments, data source sampling, with a combined collection techniques, data analysis is inductive / qualitative and qualitative research results emphasize more on the meaning of a research result.

The method used by the researchers is descriptive method. Natsir, M (2005, p. 65) argues that: "Descriptive research method is a research method that describes a condition or an event systematically, factually, and be accurate about facts, traits, and relationships among the phenomena investigated. "As for the participants or subjects in this study is the orphanage caretaker, orphanage caregivers and children in the Insan Kamil Mandiri orphanage. This is done so that there is a comparison between one statement with another statement. 
This research was conducted at the Insan Kamil Mandiri orphanage at Cihanjuang Rahayu Street No. 81 B, Cibabat Village, North Cimahi District, Cimahi City.

Data collection techniques in this study are through observation, interviews, literature study and documentation study. The observations carried out in this study are participatory observation, where researchers are involved in the daily activities of people who are being observed or used as sources of research data. In this study used in- depth interview techniques. The interviews were conducted with caregivers and orphanage administrators, and 4 foster children living in the Orphanage. In addition, researchers also use literature study techniques. This technique is done by reading, study and study the literature in order to get clear in doing research reports. The documentation collected by the researcher is related to all activities carried out by the orphanage, foster child data, and foster child activity schedules.

\section{RESULTS AND DISCUSSION}

\section{A description of the type of foster care applied at the Kamil Mandiri Orphanage in developing children's social skills}

For children who live in an orphanage, the role of caregivers as surrogate parents is one of the most important factors in supporting a child's development. When caregivers provide a positive parenting style, the resulting impact is that the child experiences good development.

Based on the analysis of researchers, that the phenomena that occur and are faced by children in this orphanage, particularly the most dominating namely on the issue of transitional shelter, from living at home with family and then going to an orphanage. This transition process includes how children get along, behave and interact with friends and caregivers, in this case the child is required to be able to adjust to the atmosphere in the orphanage.

In addition, another phenomenon is also faced by the children in this orphanage associated with social relationships with people around them. Seeing the conditions that children in this orphanage have character, age, and different backgrounds where they are required to live in the same place for a long time.

Based on the analysis of researchers that parenting is applied at the Insan Kamil Mandiri orphanage in developing children's social skills is a type of democratic parenting. This parenting is characterized by the open attitude between children and caregivers. Children are given the freedom to express opinions, his feelings and desires and learn to be able to respond to the opinions of others. Caregivers act as givers of opinion and consideration of children's activities.

In addition there is a two-way communication between caregivers and children. A decision is taken together by considering (the benefits) of both parties. This is illustrated through the compromise between child and caregiver, for example in giving punishment when a child makes a mistake. The caretakers and caregivers at the orphanage of the Insan Kamil Mandiri orphanage have a big part in the care process given to foster children.

This is in line with Silalahi and Meinarno (2010, p. 165) who suggest that authoritative parenting patterns or democracy is characterized by three parenting behaviors, that is; warmth, balance of power, and demandingness. 


\section{Implementation of Parenting} Practices at the Insan Kamil Mandiri Orphanage in Developing Children's Social Skills

Implementation of parenting here is researchers explore information related to how the adoption of parenting associated with several dimensions of children's social skills that are the focus of the discussion in developing children's social skills at the Insan Kamil Mandiri orphanage.

Gospor Nabor (in Bardawi Barzan: 1999: 5) explains that "Orphanage is a social service institution established by the government and the community, which aims to assist or provide assistance to individuals, community groups in an effort to meet the needs of life " In this regard, according to the results of the analysis of researchers that functional structural theory is closely related to this discussion which is related to the implementation of parenting that is applied at the Insan Kamil Mandiri Orphanage. Where this theory describes the interactions which are interconnected with each other. In accordance with the theory of structural functionalism according to Parson that in a system there are four important functions needed, namely Adaptation (A), Goals Attention (G), Integration (I), and Latency (L).

The first stage is the adaptation (adjustment). In this phase defined pattern adaptation carried out by a child who had to enter the environment of the orphanage. Therefore this is the role of a caregiver to provide an approach that is tailored to the child's character.

The second stage is Goal Attainment, a system must define and achieve its main objectives. In this case when the adaptation stage of a child has been passed then the next stage strives to achieve the goals of the orphanage, one of which is the inculcation of social values based on the dimensions of social skills found by Caldarella and Merrell (in Gimpel \& Merrell, 1998) that is, related to relationships with peers; obedience; and assertive behavior.

\section{a. Relationship with Peer Relations}

In this dimension is illustrated by the positive behavior towards peers such as praising or advise others, offer help to others, share with one another, and so on. As for implementation adopted by the board of Insan Kamil Mandiri orphanage is depicted through forms of care and habituation through activities that support the development of social skills.

Form of parenting is not separated from the caregiver's role as an educator, motivator and as the giver of good examples. Caretakers and caregivers give equal rights and obligations to children in the sense that they complement and respect each other. This is done to avoid jealousy among children who cause discord. Caregivers in acting always give reasons to children, encourage each other to help and act objectively, firm but warm and understanding. This democratic parenting has a positive influence on children's development and behavior. With democratic affirmation, children have confidence in solving problems. In addition, several activities that support the development of children's social skills are also carried out at institutions such as learning activities, play and sport together.

\section{b. Obedience}

Insan Kamil Mandiri Orphanage applies a set of rules that are applied to foster children. The implementation implemented by caregivers is by conducting supervision and guidance of all children's activities. Then the enforcement of penalties for children 
who break the rules, and appreciation for children who are able to obey the rules. Punishment is given due to various considerations, two-way communication between caretakers and children, meaning that the punishment is not done arbitrarily. The punishment given is educational, it means punishment which gives lessons to children. Giving rewards or rewards to children is also done to provide motivation to children to always follow the rules in accordance with expectations. In this dimension, indicating someone who can follow the rules and expectations, using a good time, and so on.

\section{c. Assertive behavior}

The attitudes, behavior and habits of the caretakers at this orphanage will be seen, assessed and imitated by foster children, so the child will behave as exemplified by the caretaker, including assertiveness in children. Children are able to communicate well, capable of using thoughts and ideas, submit requests and help, express pleasant feelings that are pleasant and so forth.

The implementation that implemented by the administrator of the orphanage of Insan Kamil Mandiri, illustrated through the form of care, among others, with; caregivers should always be friendly in any way towards foster children; make demands according to maturity and set reasonable limits in the child; always bermpati in children; give children the opportunity to express opinions and respect their opinions; provide motivation and

encouragement so that children can actively socialize; instill responsibility in all matters; teach children to always be honest; the need for openness between caregivers and children.

The third stage is integration, which is a system must regulate the interrelationships of its component parts. That is, in this stage the focus is on communication and cooperation of each component in a system. Thus in practice the caregivers and foster children must maintain mutual communication and cooperation in an effort to achieve the goals that were previously aspired.

The last stage is latency, this stage shows that a system must complete, maintain, and improve cultural patterns. This stage of latency is seen in the care process that is in the orphanage by implementing a routine evaluation which is carried out once a month involving all children.

\section{Inhibiting Factors Faced in the Orphanage of Insan Kamil Mandiri Individuals in Developing Children's Social Skills}

There are several obstacles experienced by the Insan Kamil Mandiri orphanage related to their care in developing social skills, both those from internal and external. Internal inhibiting factors experienced at the Insan Kamil Mandiri orphanage are related to the background of the child when he is still in his home family environment. Where there is a need for a special approach by the caretaker to find out appropriate care for children. In addition, the limitations of caregivers also become one of the inhibiting factors experienced at the Insan Kamil Mandiri orphanage. Because the number of children who are not proportional to the number of caregivers makes these caregivers have to be more extra in terms of child assistance.

Then external factors that become obstacles are related to the environment of children, especially the association of children at school. In addition to activities at the orphanage, children 
also have outside activities such as school activities which take quite a long time, ie morning to afternoon and even until evening.

This makes the children stay longer outside the orphanage and get a different atmosphere too. Of course the things that according to the caregivers become an obstacle is the environment of children's friendship where they do not necessarily get a good environment.

\section{Efforts Made at the Insan Kamil Mandiri Orphanage in Overcoming Existing Obstacles}

Performed various preventive ways to overcome further problems. Related to the characteristics and backgrounds of different children, the effort made is through a personal approach. This is where the caregiver's role is not just as a motivator or booster, but as a guide and facilitator of good service for children. Efforts to understand the child's character will succeed if a caregiver has the nature, certain abilities and skills that are additional driving factors for success. In addition, efforts by the Insan Kamil Mandiri orphanage were also carried out to overcome obstacles related to inhibiting factors originating from the child's environment. The efforts made by establishing cooperation between orphanages and schools. Usually the orphanage carries out monitoring to every place the child goes to school. This is done with the aim that the caregiver knows very well how the association of children in school.

\section{CONCLUSION}

First, a picture of the pattern of care adopted at the Insan Kamil Mandiri Orphanage in the development of social skills is illustrated with an open attitude between children and caregivers. Children are given the freedom to express opinions, feelings and his desire and learn to be able to respond to the opinions of others. A decision is taken together by considering (the benefits) of both parties. One of them is related to punishment and appreciation for children. The type of parenting applied is democratic parenting.

Second, the implementation of parenting that is applied in the development of children's social skills at the Insan Kamil Mandiri Orphanage is carried out with various processes. The first is a process of adaptation, Usually what is done is a personal approach to find out how are the characteristics and the child's background so that the caregiver can find out how appropriate care is. The second is Goal Attainment, this phase is seen when inculcating related social values with the dimension of social skills that is the focus of the study conducted through a form of care and refraction includes motivation, enthusiasm and support so that children are able to achieve success when they later live in society. Third integration, in this phase the focus is on communication and cooperation of every component in a system. Fourth is latency, this phase is seen in the care process that is in the orphanage by implementing a routine evaluation which is carried out once a month involving all children.

Third, in the process of developing children's social skills at the orphanage of Insan Kamil Mandiri, which of course is inseparable from the inhibiting factors both inhibitors originating from within and those from outside. The inhibiting factors derived from within include the limitations of caregivers, Different backgrounds and characteristics of children. Then external factors that become obstacles are related to the environment of children, especially the association of children at school. 
Efforts made by the board administrator in overcoming related obstacles with the limitations of the caregiver is through coordination and cooperation, both between caregivers with other caregivers, or with children. Related to the characteristics and the child's different backgrounds, namely by making a personal approach to the child, value inculcation and habituation through activities that support the development of children's social skills. other than that relating to the factors of the environment, especially in the association of children at school the effort is to coordinate with the school, the goal is to find out clearly how the association of children in school.

\section{REFERENCES}

Barzan. B. (1999). Panti Asuhan Sebagai Lingkungan Keluarga. Yogyakarta. Rineka Cipta

Gimpel, G. A., \& Merrell, K. W. (1998). Social Skills of Children and Adolescent: Conceptualization, Assessment,Treatment. New Jersey: Lawrence Erlbaurn Associates Publisher.

Illahi, Mohammad Takdir. (2013). Quantum Parenting: Kiat Sukses Mengsuh Anak Secara Efektif dan Cerdas. Yogyakarta: Kata Hati.

Lestiawati. (2013). Pengaruh pola asuh orang tua terhadap kemampuan sosial anak usia 6- 7 Tahun. Jurnal Ilmiah P2TK PAUDINI. Vol.8(2).

Mahmud, Gunawan, H. \& Yulianingsih, Y. (2013). Pendidikan Agama Islam Dalam Keluarga. Jakarta: Akademia Permata.
Madjid, dkk. (2016). Peran Nilai Budaya Sunda Dalam Pola Asuh Orang Tua Bagi Pembentukan Karakter Sosial Anak (Studi Deskriptif Di Desa Suntenjaya Kec. Lembang Kab. Bandung Barat) : International Journal Pedagogy Of Social Studies. Vol. 1(1)

Natsir, M. (2005). Metode Penelitian. Jakarta: Ghalia Indonesia.

Purnamasari, D. (2016). Implementation of Authentic Learning Model In Social Learning For Depelopment Of Student's Social Skills (Classroom Action Research at class of VII A in SMP Negeri 7 Bandung) : International Journal Pedagogy Of Social Studies. Vol. 1(2)

Silalahi, K dan Meinarno, E, A. (2010). Keluarga Indonesia:Aspek dan Dinamika Zaman. Jakarta: PT Raja Grafindo Persada

Sugiyono. (2008). Metode Penelitian Pendidikan (Pendekatan Kuantitatif, Kualitatif, dan $R \& D$. Bandung: Alfabeta Suhartiwi. (2017). Meningkatkan Keterampilan Sosial Melalui Kegiatan Bermain Peran Dan Layanan Bimbingan Kelompok. Jurnal PPKn \& Hukum. Vol. 12(2)

Widyastuti (2011). Pelatihan Dasar Untuk Meningkatkan Keterampilan Sosial Siswa Sekolah Dasar (Studi Pada SDN 5 Bangsri Jepara). Skripsi. Jurusan Psikologi. Fakultas Ilmu Pendidikan. Universitas Negeri Semarang. 